\title{
Tolerance of Very Hot Humid Environments by Highly Acclimatized Bantu at Rest
}

\author{
C. H. WYNDHAM, C. G. WILLIAMS, J. F. MORRISON, A. J. A. HEYNS, and J. SIEBERT \\ From the Human Sciences Laboratory and Physical Sciences Laboratory, \\ Transvaal and Orange Free State Chamber of Mines, fohannesburg, South Africa
}

In order to know as much as possible about human reactions under conditions of extreme ambient air temperatures, and about the ability of men to survive under these conditions and to assist in their own survival, a series of studies was made in which groups of Io men were exposed to temperature conditions ranging from $96^{\circ} \mathrm{F}$. to $104^{\circ} \mathrm{F}$. wet bulb (W.B.). Rigid criteria were employed to decide when men should be withdrawn from the test conditions. These were: $(a)$ reaching a rectal temperature of $104^{\circ} \mathrm{F}$., $(b)$ suffering from repeated attacks of heat collapse which prevented the subject from standing erect, and (c) suffering a change in temperament and being no longer susceptible to instructions.

At W.B. temperatures of $104^{\circ} \mathrm{F}$. and $102^{\circ} \mathrm{F}$. the rectal temperatures of the men continued to rise in a straight line until they reached $104^{\circ} \mathrm{F}$. There was no tendency for the rectal temperature to reach a steady state. At $100^{\circ} \mathrm{F}$. W.B. there was a definite tendency in the rectal temperatures towards a steady level, but a steady state was not reached until the rectal temperatures had reached $104^{\circ} \mathrm{F}$. The same general trend was seen at $98^{\circ} \mathrm{F}$., but the time taken to reach a steady state was increased considerably. At $96^{\circ} \mathrm{F}$. the rectal temperatures reached a steady level of between $102^{\circ} \mathrm{F}$. and $103^{\circ} \mathrm{F}$. after about 12 hours of exposure. Superimposed on this steady level was a clearcut circadian rhythm in rectal temperature.

At $104^{\circ} \mathrm{F}$. the mean heart rate continued to rise until the men were withdrawn when it had reached 148 beats per minute. In all the other air conditions, the heart rates reached a relatively steady level and the maximum level attained was proportionate to the severity of the air conditions.

The sweat rate increased steadily between $96^{\circ} \mathrm{F}$. and $100^{\circ} \mathrm{F}$. W.B. from $130 \mathrm{ml}$./hour to $300 \mathrm{ml}$./hour. Above $100^{\circ} \mathrm{F}$. it increased sharply to reach $800 \mathrm{ml}$./hour at $102^{\circ} \mathrm{F}$. and $875 \mathrm{ml}$./hour at $104^{\circ} \mathrm{F}$. W.B. In contrast to the sweat rate, the hourly rate of water intake did not alter between $96^{\circ} \mathrm{F}$. and $100^{\circ} \mathrm{F}$. W.B., being approximately constant at $150 \mathrm{ml}$./hour, but at $102^{\circ} \mathrm{F}$. and $104^{\circ} \mathrm{F}$. W.B. it rose sharply to $310 \mathrm{ml}$./hour and $330 \mathrm{ml}$./hour respectively. The hourly urine output was $95 \mathrm{ml}$./hour at $96^{\circ} \mathrm{F}$. W.B. but fell to 50 $\mathrm{ml}$./hour at $98^{\circ} \mathrm{F}$. W.B. and declined further to $35 \mathrm{ml}$./hour at $104^{\circ} \mathrm{F}$. W.B.

At $96^{\circ} \mathrm{F}$. and $98^{\circ} \mathrm{F}$. W.B. the water intake was approximately equal to the rate of sweat loss, but at $100^{\circ} \mathrm{F}$. the sweat rate increased without any rise in water intake, so that the difference was about 150 $\mathrm{ml}$./hour. At $102{ }^{\circ} \mathrm{F}$. and $104^{\circ} \mathrm{F}$. W.B. the rate of sweating increased sharply. Although the rate of drinking also rose, the difference between intake and output had also increased to about $550 \mathrm{ml} . /$ hour at I04 ${ }^{\circ} \mathrm{F}$. W.B.

The curve of the average rate of dehydration is very simila: to that representing the rate of sweating. There was little difference in the rate of dehydration between $96^{\circ} \mathrm{F}$. and $98^{\circ} \mathrm{F}$. W.B., the rate being $80 \mathrm{ml}$./hour, but at $100^{\circ} \mathrm{F}$. it rose to $210 \mathrm{ml}$./hour. Above $100^{\circ} \mathrm{F}$. W.B. the rate of dehydration rose sharply as the rate of water intake lagged further behind the rate of sweating; it was $510 \mathrm{ml}$./hour at $104^{\circ} \mathrm{F}$. W.B.

The main psychological effects were on the men's temperaments. A number of men became aggressive, a few became hysterical, and a few maintained a stoical silence. At $96^{\circ} \mathrm{F}$. W.B., when the men remained in the climatic rooms for 48 hours, there were periods of aggressive behaviour which alternated with apathy. Electroencephalograms were done on some subjects. No abnormalities of any kind were evoked or caused by exposure to heat.

The tolerance times before which men, whe were initially cool, would not have reached their limit of tolerance to heat were estimated.

Received for publication June I, 1967. 
Modern engineering developments in ventilation and air conditioning have allowed men to penetrate into regions where the ambient air temperatures are very high. Examples are the cooling arrangements in the cockpits of supersonic aircraft, the ventilated suits used for fighting fires, the ventilation of working places in mines by means of powerful fans, and the refrigeration of the air sent into these working places. A failure in such cooling arrangements could expose men to conditions of severe heat stress. It is, therefore, desirable to know as much as possible about human reactions under these conditions and about the ability of man, under these conditions, to survive and assist in his own survival.

Research has been carried out on this subject, notably in the British Medical Research Council's Climate and Working Efficiency Unit at Oxford (Bell, Hellon, Hiorns, Nicol, and Provins, 1965; Provins, Hellon, Bell, and Hiorns, 1962) and in the United States Army's Research Institute for Environmental Medicine at Natick, Massachusetts (Goldman, Green, and Iampietro, I965; Iampietro and Goldman, 1965). This research has, however, left a number of questions unanswered. Thus

(i) the states of acclimatization of the subjects of the above experiments were not always clearly apparent, so that the influence of the state of acclimatization on tolerance time has not been fully explored.

(ii) the criteria employed for deciding when men had reached the limit of their tolerance were either arbitrary or largely subjective; it is unlikely, therefore, that the tolerance times bear any relationship to the length of time men could be exposed to severe heat before they would be in serious danger.

With the object of putting this question on a firmer basis, the following more rigid criteria were employed in the present series of experiments:

(a) reaching a rectal temperature of $104^{\circ} \mathrm{F}$., because there is a risk of the man developing heat stroke if exposure is continued for some hours with a body temperature at this level;

(b) suffering from repeated attacks of heat collapse which prevents the subject from standing erect, because in such circumstances the subject might not be able to look after his own safety or that of others;

(c) suffering a change in temperament and being no longer susceptible to instruction, because in this event the subject might become unmanageable and this could endanger his own safety as well as that of any group of which he were a member.

Using these criteria, studies were carried out in climatic rooms with acclimatized Bantu subjects sitting at rest. Bantu subjects were chosen because they form the bulk of the underground labour force in the South African gold mines.

Subsequent papers will deal with the tolerance times of acclimatized Bantu performing physical work and of Bantu in the unacclimatized state.

\section{Methods}

Experimental Ten acclimatized volunteer subjects were exposed at rest to each of the following air conditions:

(a) $107^{\circ} \mathrm{F}$. dry-bulb (D.B.) and $104^{\circ} \mathrm{F}$. wet-bulb (W.B.) temperatures;

(b) $105^{\circ}$ F. D.B. and $102^{\circ} \mathrm{F}$. W.B.;

(c) $103^{\circ}$ F. D.B. and $100^{\circ}$ F. W.B.;

(d) IOI ${ }^{\circ}$ F. D.B. and $98^{\circ}$ F. W.B.; and

(e) $99^{\circ} \mathrm{F}$. D.B. and $96^{\circ} \mathrm{F}$. W.B.

Air velocity was $80 \mathrm{ft} / \mathrm{min}$. in all the experiments. The subjects entered the climatic room between 8 a.m. and 9 a.m. without having had breakfast. They were provided with shorts, but none wore them after the first few hours. The subjects were allowed to adopt any posture they wished. In experiments $(d)$ and $(e)$, which were of longer duration, the men generally lay sprawled on the floor of the climatic room with their limbs spread as far apart as the space in the room would allow.

Rectal temperatures and heart rates were measured every hour until the rectal temperature rose above $103^{\circ} \mathrm{F}$., after which measurements were made every 15 minutes. The men were weighed at the beginning and at the end of the experiments. It had been the intention to weigh the men every hour, but under the air and humidity conditions of the experiments it proved impossible to do this in the climatic room to the required degree of accuracy. Water at room temperature (tepid) was given ad lib. The men were encouraged to drink water but they showed little relish for it. In the long experiments, i.e., at $98^{\circ} \mathrm{F}$. W.B., emergency rations were provided at first, but these were rejected by the men. Fresh meat, prepared to the men's taste, was accepted by them.

Electroencephalograms (E.E.G.s) were taken by trained observers on all 50 men before they entered the climatic chambers. They were repeated on 4I men as soon as they emerged from the climatic chambers and again on 34 of the 4I men after they had cooled down to normal body temperatures.

Bantu psychologists, or trained Bantu observers, from the National Institute for Personnel Research were in the climatic rooms with the subjects in most of the experiments and their function was to record their observations on the behaviour of the 
men and to note any changes in temperament and in the attitudes of the men towards the observers and towards each other in the group. These observers did not stay in the climatic rooms throughout the periods of exposure of the subjects in order to avoid any possible influence of heat on their observations. The observations recorded in the results are, therefore, in the main by Bantu psychologists on men of the same ethnic group under conditions of heat stress.

Subjects Each subject was a volunteer and was briefed by an experienced Bantu interviewer of the National Institute for Personnel Research on the reasons for and the nature of the experiments. It was explained that in an accident men could be exposed to very high temperatures and humidities and that in order to plan effective rescue operations mine managers must know how long they would have in hand before the men reached the limit of their tolerance. The results would, therefore, be of practical benefit for their own and their fellow workmen's protection. The volunteers were told that they would find the conditions very unpleasant, but they were reassured that the medical staff would be in attendance at all times and that frequent measurements of heart rate and rectal temperature would be taken so that the subjects would not be in any danger. The subjects were asked to continue with the experiment until the medical officer decided that they could leave the room. No additional incentives were employed.

The 50 subjects studied during the experiments were an average cross-section of the Bantu workers in the mine and comprised ro workers who normally work on shovelling rock, eight on building stone walls, six on moving timber and building packs, six on tramming, five on machine drills, five on attending to pipes and tracks, two winch drivers, and eight who were engaged on a miscellany of tasks. All the men had worked in hot conditions for a minimum period of three months before the study and they could be regarded as highly acclimatized. The average wet-bulb temperature at which the men worked was $89.4^{\circ} \mathrm{F}$. with a range from $81 \cdot 4^{\circ}$ to $92 \cdot 3^{\circ} \mathrm{F}$. (there were few working below $86^{\circ} \mathrm{F}$.).

The men had an average height of $166.6 \mathrm{~cm}$. (standard deviation of $6.21 \mathrm{~cm}$.) and an average weight of $62.34 \mathrm{~kg}$. (standard deviation $5.91 \mathrm{~kg}$.).

\section{Results}

Rise in Rectal Temperatures The rectal temperatures for each individual are plotted in Fig. I (a to d) for wet-bulb temperatures of $96^{\circ} \mathrm{F}$., $98^{\circ} \mathrm{F}$., $100^{\circ} \mathrm{F}$., $102{ }^{\circ} \mathrm{F}$., and $104^{\circ} \mathrm{F}$. (with the air almost saturated with water vapour) and an air velocity of $80 \mathrm{ft} /$ minute.

In all the various air conditions the rate of rise of the rectal temperature was faster in the second hour than in the first hour of exposure. The mean rates of rise in rectal temperature of the ro subjects for the three most severe conditions are given in Table I.

TABLE I

InCrease in Rectal Temperature ( $\left.{ }^{\circ} \mathrm{F}.\right)$ : Averages For GROUPS

\begin{tabular}{c|c|c}
\hline W.B. Temperature & First Hour & Second Hour \\
\hline $104^{\circ} \mathrm{F}$. & $2 \cdot 85$ & $4 \cdot 1 \mathrm{I}$ \\
$102^{\circ} \mathrm{F}$. & $2 \cdot 44$ & $2 \cdot 70$ \\
$100^{\circ} \mathrm{F}$. & $1 \cdot 00$ & $2 \cdot 30$ \\
\hline
\end{tabular}

At wet-bulb temperatures of $104^{\circ} \mathrm{F}$. and $102^{\circ} \mathrm{F}$. the rectal temperatures after the first hour continued to rise in a straight line until the temperature of $104^{\circ} \mathrm{F}$. was reached. The subjects were then withdrawn. At $104^{\circ}$ F. W.B. the mean time for the group to reach a rectal temperature of $104^{\circ} \mathrm{F}$. was I hour 35 minutes (range I hour 30 minutes to 2 hours 24 minutes); at $102^{\circ} \mathrm{F}$. W.B. the mean time was 2 hours 15 minutes (range 2 to 3 hours).

At $100^{\circ} \mathrm{F}$. W.B. there was a definite tendency towards a steady level in the rectal temperatures after the second hour of exposure, but this was not attained before the rectal temperatures had reached I0 ${ }^{\circ} \mathrm{F}$. There were considerable differences between individuals in the rate of rise of rectal temperature, so that the time taken to reach $104^{\circ} \mathrm{F}$. varied between 3 hours 15 minutes and 8 hours. The same general trend was seen at $98^{\circ} \mathrm{F}$. W.B. where the time taken for the men's rectal temperatures to reach $104{ }^{\circ} \mathrm{F}$. varied between 6 hours 45 minutes and 35 hours.

At a wet-bulb temperature of $96^{\circ} \mathrm{F}$. all these highly acclimatized men achieved a steady level of rectal temperature at a mean of between $102^{\circ} \mathrm{F}$. and $103^{\circ} \mathrm{F}$. after about 12 hours' exposure. This level was maintained for the remainder of the period of 48 hours. Superimposed upon this steady level was a clearcut circadian rhythm in rectal temperature, which took the form of a slow fall in rectal temperature between midnight and 6 a.m., during which time the men were sleeping, and a slow rise during the day to reach a maximum in the late afternoon and evening. The range of this fluctuation was about $\mathrm{I}^{\circ} \mathrm{F}$. 


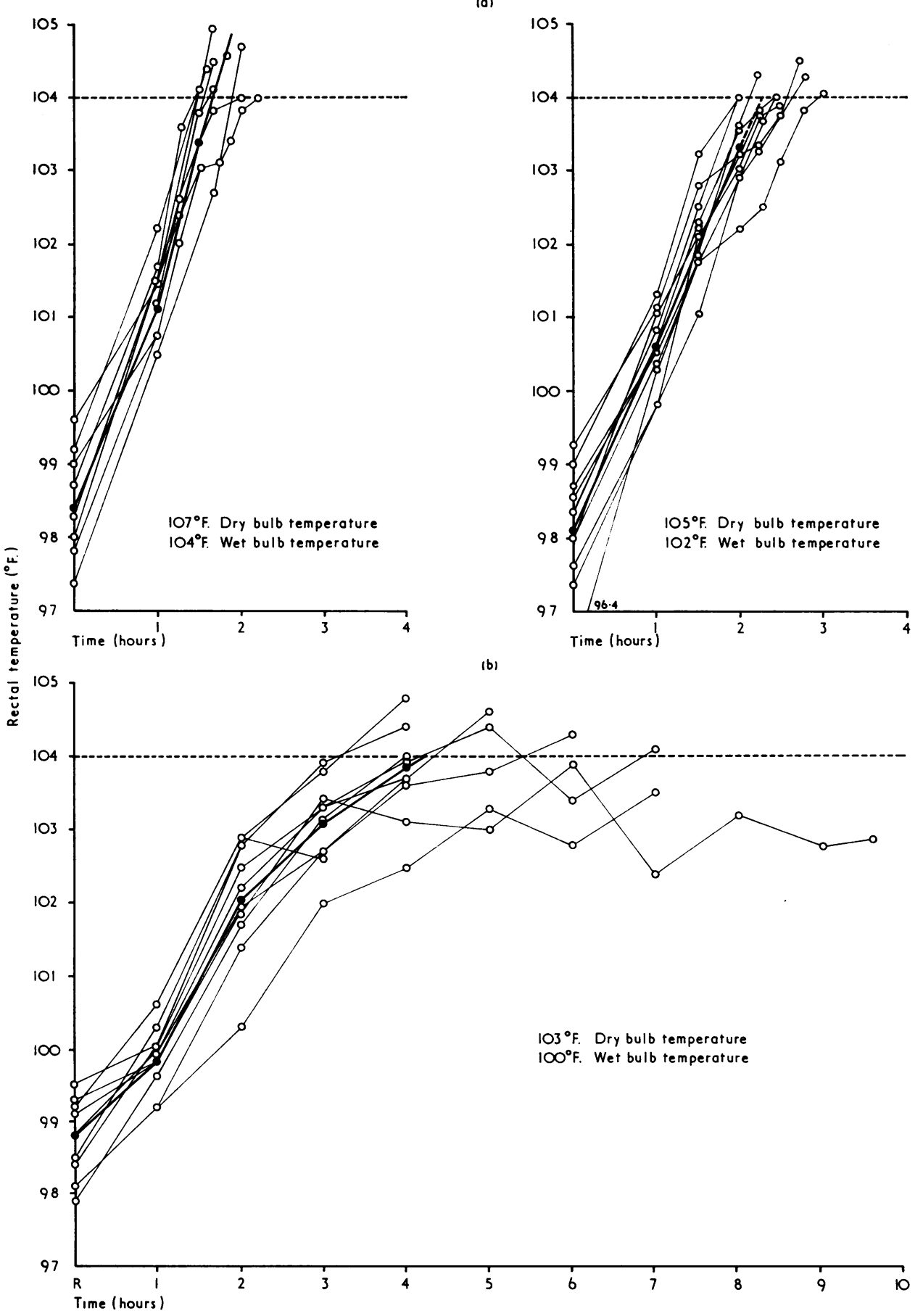

FIG. I. Rectal temperature responses with time (a) $104^{\circ} \mathrm{F}$. and $102^{\circ} \mathrm{F}$. W.B. (b) $100^{\circ} \mathrm{F}$. W.B. 


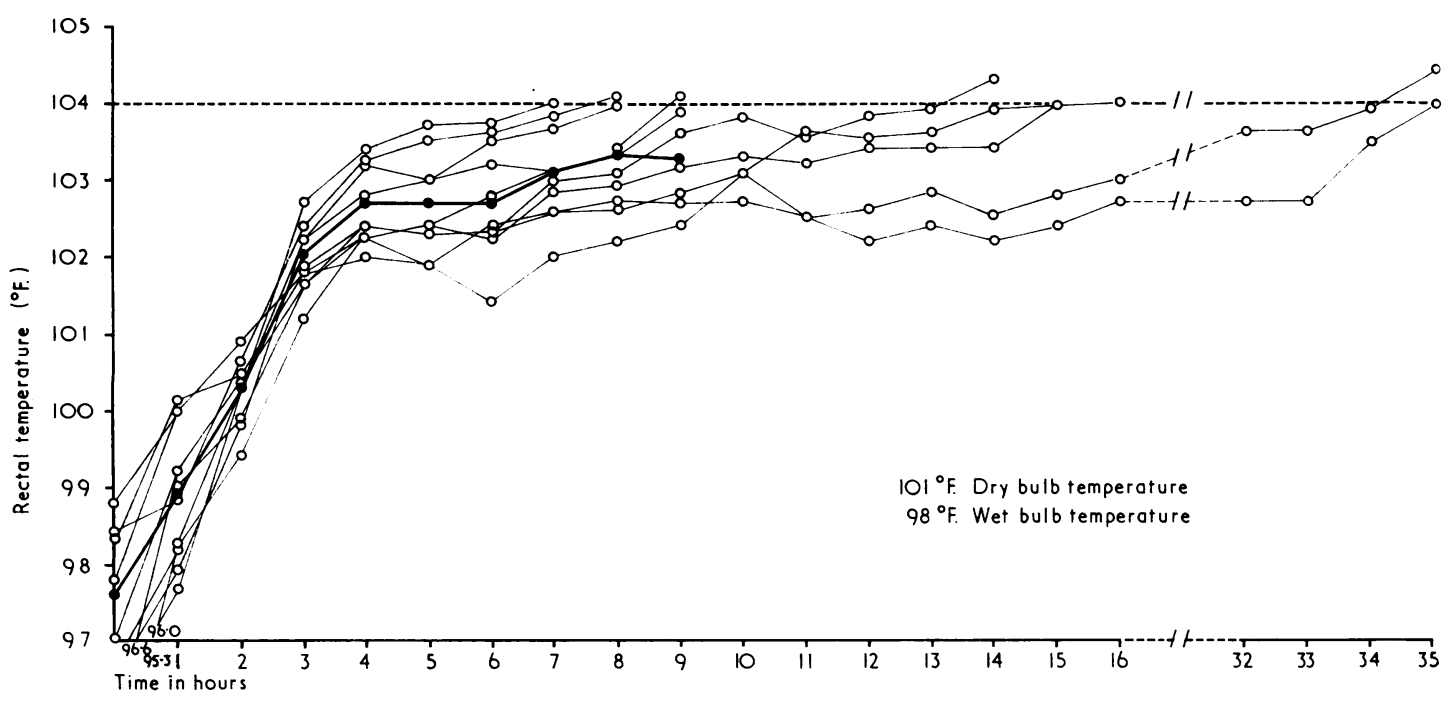

FIG. I(c). Rectal temperature responses with time: $98^{\circ} \mathrm{F}$. W.B.

Circulatory Reactions The mean heart rates during exposure to heat at the five different air conditions are plotted in Figure 2. The rates of rise in heart rate were very rapid during the first hour of exposure and were related to the levels of air temperature (Table II).

At $104^{\circ} \mathrm{F}$. W.B. the mean heart rate continued to rise until the men were withdrawn when it had reached 148 beats per minute. In all the other air

TABLE II

Rate of Rise in Heart Rate: Averages for Groups

\begin{tabular}{c|c}
\hline W.B. Temperature & Rise in First Hour of Exposure \\
\hline $104^{\circ} \mathrm{F}$. & 64 beats $/ \mathrm{min}$. \\
$102^{\circ} \mathrm{F}$. & 58 beats $/ \mathrm{min}$. \\
$100^{\circ} \mathrm{F}$. & 32 beats $/ \mathrm{min}$. \\
$98^{\circ} \mathrm{F}$. & 21 beats $/ \mathrm{min}$. \\
$96^{\circ} \mathrm{F}$. & 23 beats $/ \mathrm{min}$. \\
\hline
\end{tabular}

TABLE III

Relationship between Maximum Heart Rate and W.B. Temperature: Averages fOR Groups

\begin{tabular}{c|c}
\hline W.B. Temperature & Maximum Heart Rate \\
\hline $104^{\circ} \mathrm{F}$. & I48 beats $/ \mathrm{min}$. \\
$102^{\circ} \mathrm{F}$. & I 42 beats $/ \mathrm{min}$. \\
$100^{\circ} \mathrm{F}$. & I28 beats $/$ min. \\
$98^{\circ} \mathrm{F}$. & II beats $/$ min. \\
$96^{\circ} \mathrm{F}$. & II 7 beats $/ \mathrm{min}$. \\
\hline
\end{tabular}

conditions, the heart rates reached a relatively steady level and the maximum level attained was proportionate to the severity of the air conditions (Table III).

In spite of the very considerable circulatory strain which the subjects experienced in the two most severe heat conditions, i.e., heart rates of 140 and 150 beats per minute for an hour, not one man collapsed. Some complained of being giddy, especially when they had to stand up for physiological measurements, but they all left the climatic room unaided and were still able to stand erect on a balance after they had left the climatic room.

Water Balances The various components of water exchange, i.e., the average hourly rates of sweating, water intake, urine output and extent of dehydration, are illustrated in Figure 3. In Fig. 4 are plotted the average 'overall' values for these same measurements.

The curves fitted to the sweat rate plotted against wet-bulb temperature are given in Figure 3. Sweat rates increased steadily between $96^{\circ} \mathrm{F}$. and $100^{\circ} \mathrm{F}$. W.B. from $130 \mathrm{ml}$./hour to $300 \mathrm{ml}$./hour. Above $100^{\circ} \mathrm{F}$. W.B. the sweat rate increased sharply to reach $800 \mathrm{ml}$./hour at $102{ }^{\circ} \mathrm{F}$. and $875 \mathrm{ml}$./hour at I0 $4^{\circ} \mathrm{F}$. W.B. In contrast with the sweat rates, the hourly rate of water intake did not alter between $96^{\circ} \mathrm{F}$. and $100^{\circ} \mathrm{F}$. W.B., being approximately constant at $105 \mathrm{ml}$./ hour, but at $102{ }^{\circ} \mathrm{F}$. and $104^{\circ} \mathrm{F}$. W.B. it rose sharply to 310 and $330 \mathrm{ml}$./hour respectively. The hourly urine output was 95 $\mathrm{ml}$./hour at $96^{\circ} \mathrm{F}$. W.B. but fell to $50 \mathrm{ml}$./hour at 
Tolerance of Very Hot Humid Environments by Highly Acclimatized Bantu at Rest

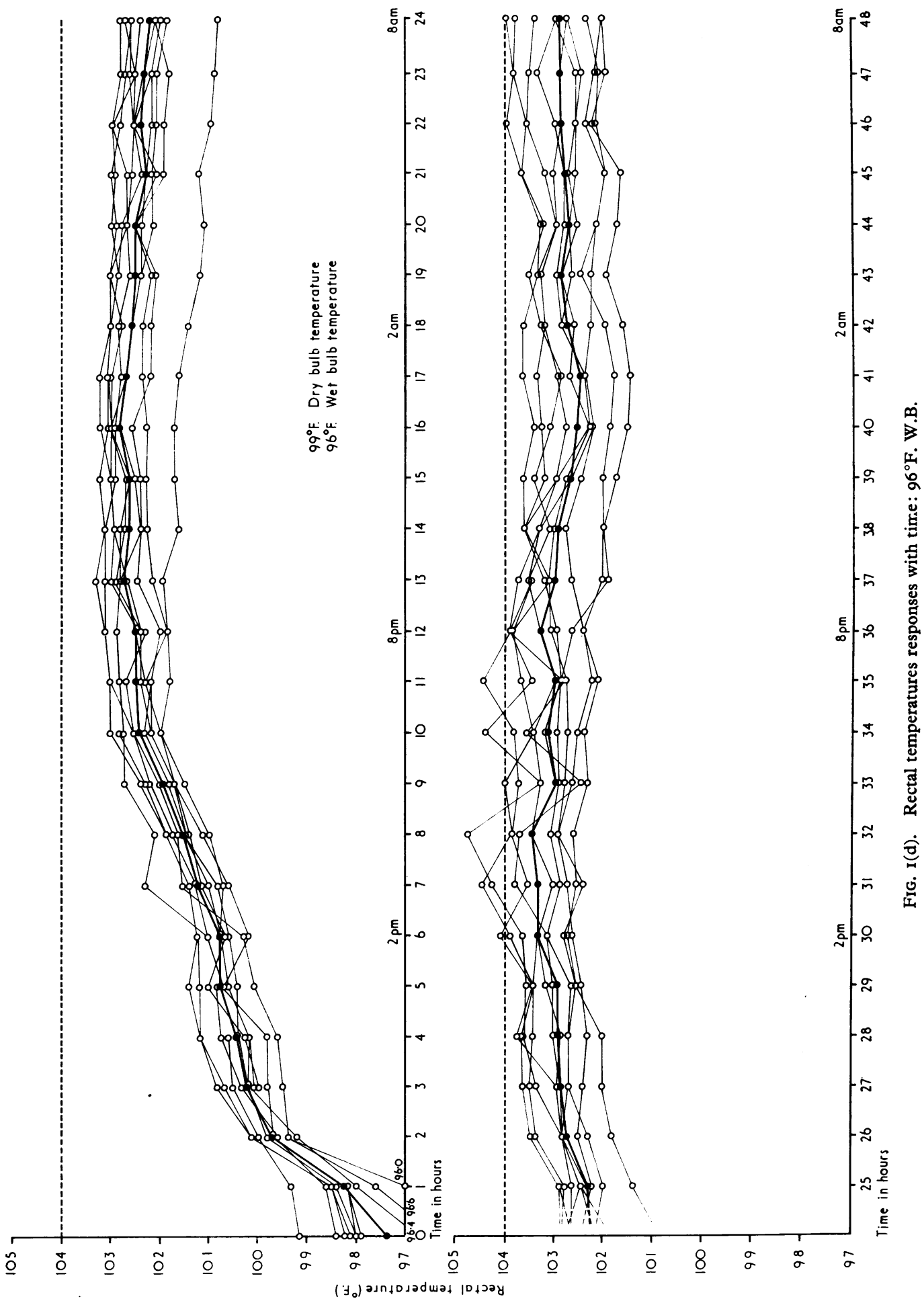




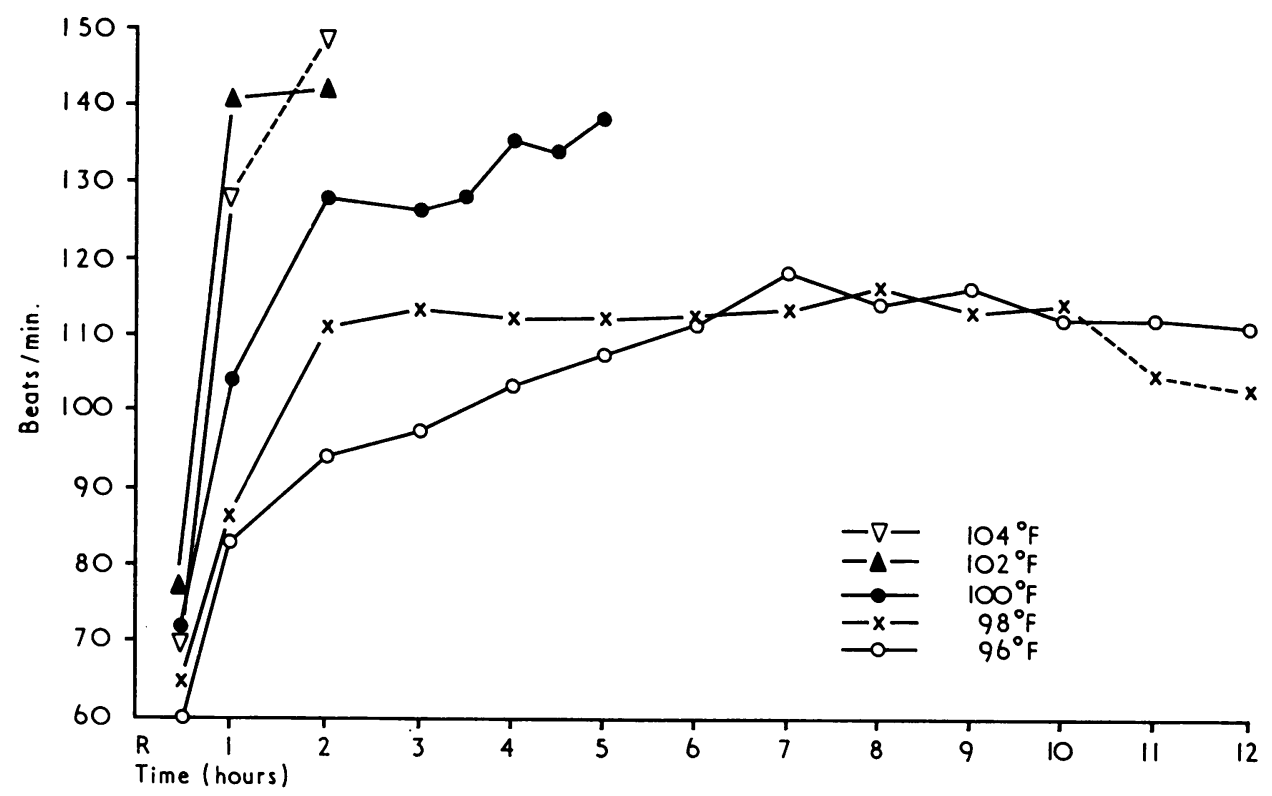

FIG. 2. Heart rates against time at various W.B. temperatures.

$98^{\circ} \mathrm{F}$. W.B. and fell further to $35 \mathrm{ml}$./hour at I04 ${ }^{\circ} \mathrm{F}$. W.B.

At $96^{\circ} \mathrm{F}$. and $98^{\circ} \mathrm{F}$. W.B. the water intake was approximately equal to the rate of sweat loss, but at $100^{\circ} \mathrm{F}$. the sweat rate increased without any rise in water intake so that the difference was about $150 \mathrm{ml}$./hour. At $102{ }^{\circ} \mathrm{F}$. and $104^{\circ} \mathrm{F}$. W.B. the rate of sweating increased sharply. Although the rate of drinking also rose, the difference between intake and output increased to about $550 \mathrm{ml}$./hour at $104^{\circ} \mathrm{F}$. air temperature.

The curve of the average rate of dehydration is very similar to that representing the rate of sweating. There was little difference in the rate of dehydration between $96^{\circ} \mathrm{F}$. and $98^{\circ} \mathrm{F}$. W.B., the rate being $80 \mathrm{ml}$./hour, but at $100^{\circ} \mathrm{F}$. it rose to $210 \mathrm{ml}$./hour. Above $100^{\circ} \mathrm{F}$. W.B. the rate of dehydration rose sharply as the rate of water intake lagged further behind the rate of sweating; it reached a level of $510 \mathrm{ml}$./hour at $104^{\circ} \mathrm{F}$. W.B.

The overall effects of air temperature on the water balances of the men, presented as a bardiagram in Fig. 4, indicate that the highest total consumption of water was $7,600 \mathrm{ml}$. at $96^{\circ} \mathrm{F}$., while the lowest value, approximately 500 to $800 \mathrm{ml}$., was at $100^{\circ} \mathrm{F}$. to $104^{\circ} \mathrm{F}$. The water intake at $98^{\circ} \mathrm{F}$. was $2,400 \mathrm{ml}$. It further indicates that at $96^{\circ} \mathrm{F}$. more than $50 \%$ of consumed water was excreted again as urine $(4,600 \mathrm{ml}$.); water intake was $1,000 \mathrm{ml}$. in excess of sweat secretion, which was $6,450 \mathrm{ml}$., and the total dehydration, or water deficit, of $3,500 \mathrm{ml}$. was only $\mathrm{I}, 000 \mathrm{ml}$. less than the total amount of urine passed. At temperatures of $98^{\circ} \mathrm{F}$., $100^{\circ} \mathrm{F}$., IO $2^{\circ} \mathrm{F}$., and $104^{\circ} \mathrm{F}$. W.B. the water intake was less than the volume of sweat excreted. At $98^{\circ} \mathrm{F}$. this difference was small, being approximately $500 \mathrm{ml}$., while at higher air temperatures sweat secretion was nearly three times the volume of water taken in. At $98^{\circ} \mathrm{F}$. and $100^{\circ} \mathrm{F}$. W.B. the urine output was about $33 \%$ of the water intake, while at $102{ }^{\circ} \mathrm{F}$. and $104{ }^{\circ} \mathrm{F}$. it amounted to $12 \%$ and $8 \%$ respectively.

A relatively constant water deficit of 1,000 to $\mathrm{I}, 300 \mathrm{ml}$. occurred at temperatures of $98^{\circ} \mathrm{F}$. to $104^{\circ} \mathrm{F}$. W.B.

Psychological Reactions The observations were made by trained Bantu observers of the National Institute for Personnel Research to avoid any bias being introduced through observations of one ethnic group under stress by observers of another ethnic group. The main psychological reactions to these very extreme hot and humid air conditions was a change in the men's temperaments. A number' of men became aggressive after the second hour at $100^{\circ} \mathrm{F}$. to $104^{\circ} \mathrm{F}$. W.B. when the rectal temperatures had risen to $103^{\circ} \mathrm{F}$. and above. A few became hysterical and a few maintained a stoical silence. Three men would not remain in the climatic rooms-one at $104^{\circ} \mathrm{F}$. and two at $100^{\circ} \mathrm{F}$. W.B. At $96^{\circ} \mathrm{F}$. W.B., when the men re- 
Tolerance of Very Hot Humid Environments by Highly Acclimatized Bantu at Rest

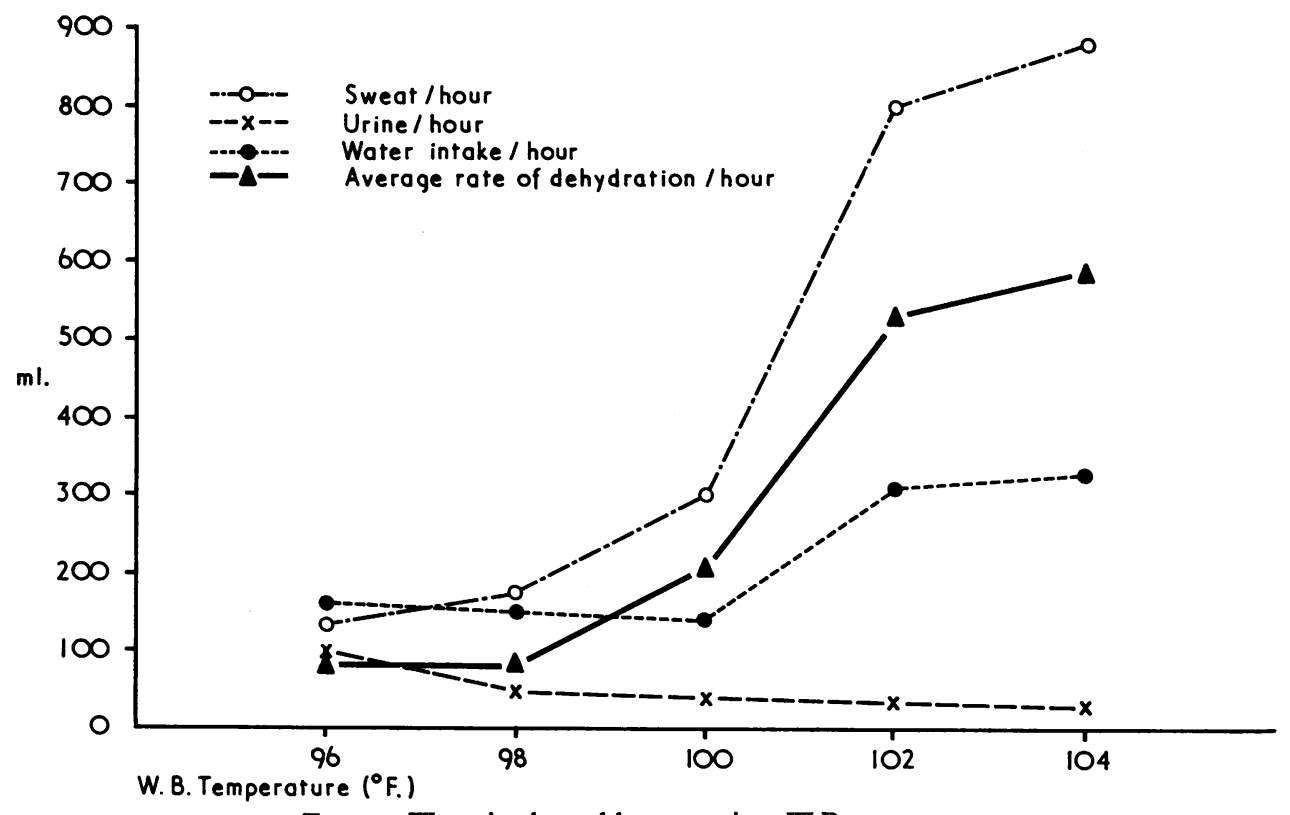

FrG. 3. Water intake and loss at various W.B. temperatures.

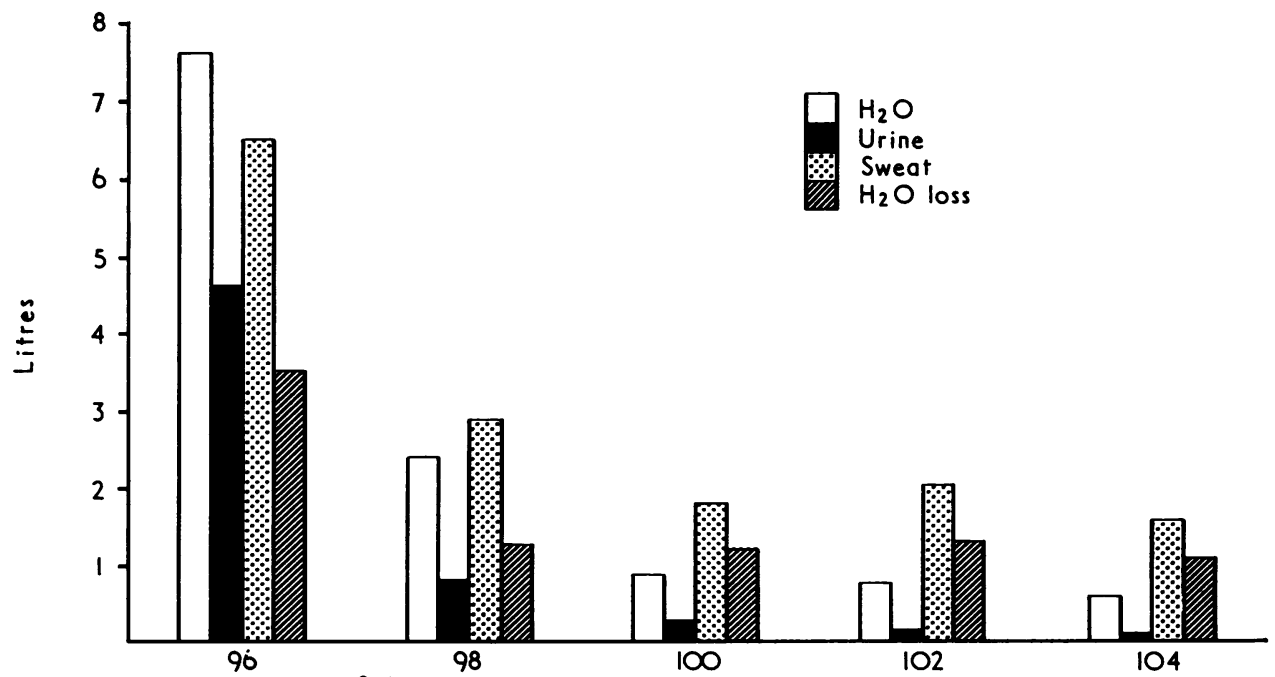

W. B. Temperature $\left({ }^{\circ} \mathrm{F}\right.$.)

FIG. 4. Water exchange at various W.B. temperatures. 
TABLE IV

Characteristic Behaviour of Men During Long-Term Exposures at $96^{\circ} \mathrm{F}$. W.B.

\begin{tabular}{|c|c|c|c|c|c|c|}
\hline Group & $\begin{array}{c}\text { Temp. } \\
W . B . / D . B .\end{array}$ & $\begin{array}{c}\text { Duration } \\
(h r s)\end{array}$ & Condition & Subject & $\begin{array}{c}\text { Age } \\
\text { (yrs) }\end{array}$ & Characteristic Behaviour \\
\hline 5 & $96 / 98$ & 48 & Rest & $\begin{array}{r}1 \\
2 \\
3 \\
4 \\
5 \\
6 \\
7 \\
8 \\
9 \\
10\end{array}$ & $\begin{array}{l}27 \\
32 \\
30 \\
30 \\
19 \\
29 \\
22 \\
49 \\
40 \\
48\end{array}$ & $\begin{array}{l}\text { Complains } \\
\text { Calm } \\
\text { Violent } \\
\text { Violent, crying } \\
\text { Violent } \\
\text { Crying, violent } \\
\text { Crying, violent } \\
\text { Very quiet } \\
\text { Talkative } \\
\text { Talkative and 'pleasant' }\end{array}$ \\
\hline
\end{tabular}

mained in the climatic rooms for 48 hours, there were periods of aggressive behaviour which alternated with apathy, when the subjects lay inert and out of contact with their surroundings. In the latter state they were difficult to arouse, and when they were required to co-operate with the observers, as for example in the taking of rectal temperatures, they became aggressive. After about 24 hours in the climatic room, i.e., at about 7 a.m. on the first morning, some of the men could only be persuaded to continue as subjects by a senior hostel official who talked to them in their own language and reiterated the objects of the experiment.

A summary of the characteristic behaviour of the men exposed at $96^{\circ} \mathrm{F}$. W.B., given by a trained Bantu psychologist, is presented in Table IV.

Electroencephalograms Electroencephalograms were recorded on all 50 of the subjects before they entered the climatic rooms. E.E.G.s were repeated on $4 \mathrm{I}$ of the men immediately after they had left the climatic rooms and were repeated again on 34 of these 4I men after they had been cooled down and their rectal temperatures had returned to normal (Nelson, 1965).

Six of the 50 control E.E.G.s showed some abnormality. The incidence of abnormality, $11 \%$, is characteristic in such population surveys (Nelson, 1965). One of the six individuals had bilateral fronto-temporal medium-high voltage bursts of 2.5-3 and 5-6 c/s activity, the latter being occasionally focal on the right side and raising the possibility of associated epileptic disorder. In the subject with the possible epileptic disorder, the E.E.G. abnormalities were more pronounced when his body temperature was raised. In the remaining five men with abnormal records there were no significant changes when the body temperatures were raised to $104^{\circ} \mathrm{F}$. In none of the other 44 cases were
E.E.G. abnormalities of any kind evoked or caused by exposure to heat.

There was also no consistent change in alpha frequency, amplitude or index with raised body temperature or re-cooling. In one group of subjects (exposed to $100^{\circ} \mathrm{F}$. air temperature) there was a significant correlation between alpha frequency and the time taken for the rectal temperature to rise to I0 $4^{\circ} \mathrm{F}$., but as similar correlations were not found in other groups this finding must be regarded as due to chance.

Six subjects became aggressive. One of them assaulted an observer; he was the individual with the E.E.G. which suggested epilepsy. The other five men who were aggressive had relatively low alpha frequencies, which cleared up after the men had cooled down at the end of the experiment.

Tolerance Times at Various Wet-bulb Temperatures The three criteria used to decide when the men had reached the end-point of their tolerance to heat are given on page 23 .

The reasons for terminating the exposures of the 50 subjects were as follows: 36 of the 50 subjects were withdrawn because their rectal temperatures had reached $104^{\circ} \mathrm{F}$., three were withdrawn when they became aggressive and would not remain in the climatic room, and one man was withdrawn after 9 hours at $100^{\circ} \mathrm{F}$. W.B. because he refused to follow instructions. Ten men stayed in the climatic room at $96^{\circ} \mathrm{F}$. W.B. for 48 hours.

In Fig. 5 the average times (for the Io men) at which the samples of Io men were withdrawn are plotted against wet-bulb temperature. A rectangular hyperbola was fitted to the plots. (The reason for using this curve and other statistical matters are dealt with in the appendix, p. 38). Also drawn in the Figure are curves which represent (I) the $99 \%$, and (2) the $90 \%$ two-sided tolerance 


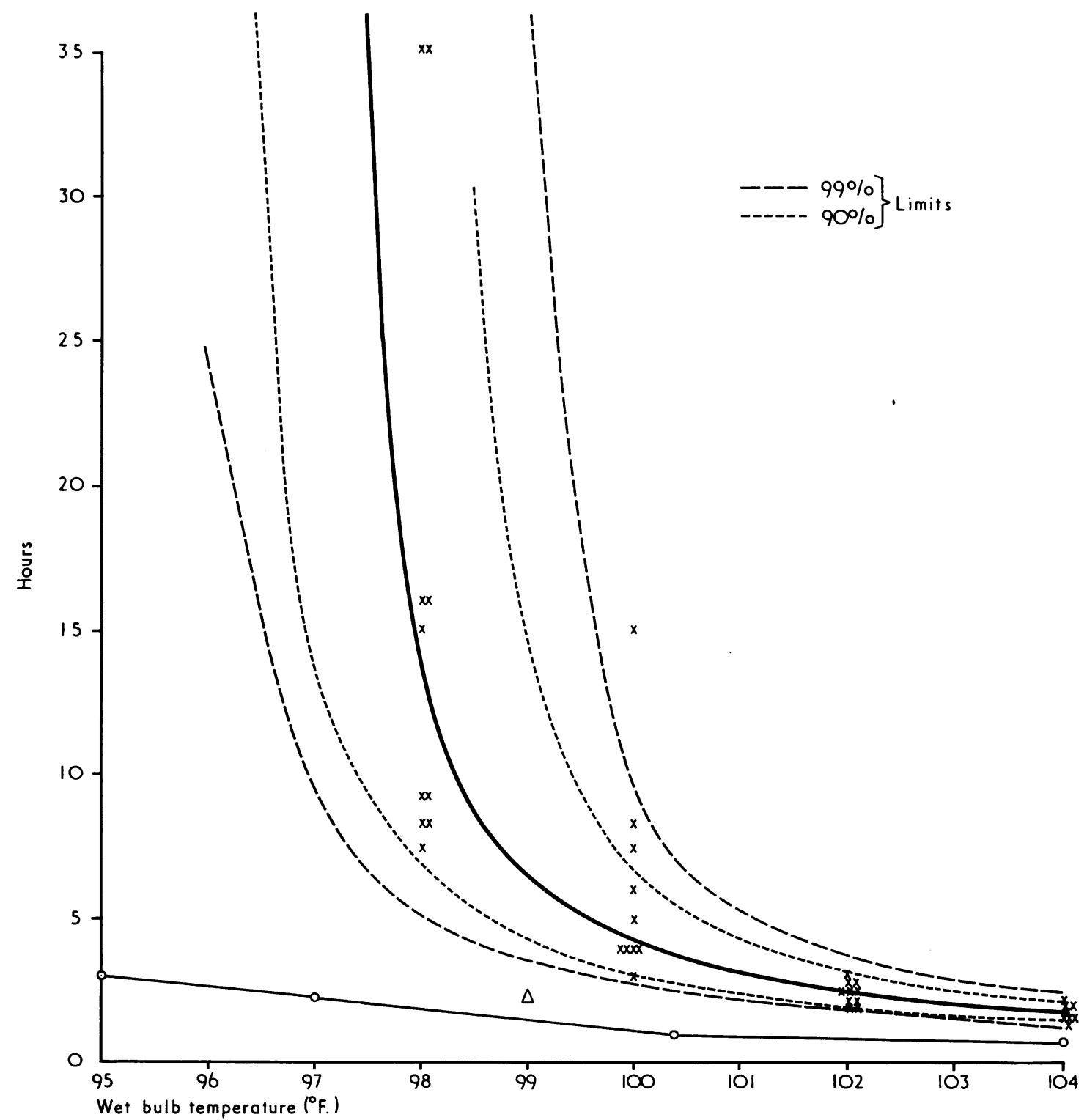

FIg. 5. Tolerance times at various W.B. temperatures (two-sided tolerance limits at $95 \%$ confidence level). $\circ \longrightarrow$ from data of Provins and others (1962). $\triangle$ from data of Ellis and others.

limits (at the $95 \%$ confidence level). From these three curves one can make an estimate of $(a)$ the time at which the 'average' acclimatized Bantu would reach the limit of tolerance at the various wet-bulb temperatures, or (b) the lapse of time before which at least 99 in 100 men would still not have reached their tolerance limits (from the $99 \%$ tolerance limits), or (c) the lapse of time before which at least 90 men in 100 would not have reached their tolerance limits (from the $90 \%$ tolerance limits). These last two estimates are at the $95 \%$ level of confidence.

From these curves estimates have been made of the lapses of time before which the 'average' acclimatized Bantu would not have reached the limit of tolerance to heat during exposure to the 
various W.B. temperatures studied and also of the lapses of time before which at least 99 in 100 and at least 90 in 100 men would not have reached their tolerance limits. These are given in Table V.

\section{TABLE V}

TIMES BEFORE WHICH MEN, WHO WERE INITIALly COOL, WOULD NOT have REAChed Their Limit OF TOLERANCE TO Heat

\begin{tabular}{|c|c|c|c|}
\hline W.B. Temp. & Average Time & $\begin{array}{c}\text { Time for at } \\
\text { least } 90 \text { in } \\
\text { roo Men }\end{array}$ & $\begin{array}{c}\text { Time for at } \\
\text { least } 99 \text { in } \\
\text { roo Men }\end{array}$ \\
\hline $\begin{array}{l}104^{\circ} \mathrm{F} . \\
102^{\circ} \mathrm{F} . \\
100^{\circ} \mathrm{F} . \\
98^{\circ} \mathrm{F} . \\
96^{\circ} \mathrm{F} .\end{array}$ & $\begin{array}{r}\text { I hours } \\
2 \frac{1}{2} \text { hours } \\
4 \frac{1}{4} \text { 'hours } \\
13 \frac{1}{2} \text { hours } \\
48+\text { hours }\end{array}$ & $\begin{array}{l}\text { I } \frac{1}{2} \text { hours } \\
2 \frac{1}{4} \text { hours } \\
3 \text { hours } \\
6 \frac{1}{2} \text { hours } \\
40 \text { hours }\end{array}$ & $\begin{array}{l}\text { I hours } \\
2 \text { hours } \\
2 \frac{3}{4} \text { hours } \\
5 \text { hours } \\
24 \frac{1}{2} \text { hours }\end{array}$ \\
\hline
\end{tabular}

\section{Discussion}

\section{Tolerance Times}

Present Results Figure 5 contains a curve which indicates the length of time after which the 'average' acclimatized Bantu could be expected to have reached the limit of tolerance as defined by the three criteria given at various high wet-bulb temperatures. At $96^{\circ} \mathrm{F}$. W.B. the average acclimatized Bantu would not be in danger even after 48 hours of exposure. At $100^{\circ} \mathrm{F}$. wet-bulb temperature, the time before the average Bantu would be at the end of his tolerance would be about $4 \frac{1}{4}$ hours. Above $100^{\circ} \mathrm{F}$., the tolerance times are short, but even at $104^{\circ} \mathrm{F}$. wet-bulb temperature the tolerance time is about $\mathrm{I} \frac{3}{4}$ hours.

It is considered that mine managers would want to know not only when the average workman, underground in the mine, would reach the limit of tolerance but also the times at which one in 100 men, and, possibly, when one in 10 men would reach the limit of their tolerance. This was done by calculating $99 \%$ and $90 \%$ 'tolerance' limits to the curve in Figure 5. The interpretation of these tolerance limits to the curve is that, to take the $99 \%$ tolerance limits, it can be stated (at the $95 \%$ level of confidence) that at least 99 in 100 observations will lie within the tolerance limits. Similarly, in the case of the $90 \%$ tolerance limits at least 90 in I00 observations would lie within the tolerance limits. Therefore, taking the $99 \%$ tolerance limits as an example, it can be predicted that at $104^{\circ} \mathrm{F}$. W.B. at least 99 in 100 men would not have reached their limit of tolerance before $\mathbf{I} \frac{1}{4}$ hours, before
2 hours at $102^{\circ} \mathrm{F}$. W.B., and so on. Similarly, the interpretation of the $90 \%$ tolerance limits is that at least 90 in 100 men would not have reached their limit of tolerance to heat before $\mathrm{I}_{2} \frac{1}{2}$ hours at I0 $4^{\circ} \mathrm{F}$. W.B., before $2 \frac{1}{4}$ hours at $102^{\circ} \mathrm{F}$. W.B., and so on.

Provins and others (1962) attempted to 'make allowances for individual susceptibility to heat stress' but they used a different approach from the one we have employed in this paper. They proposed doing this by 'using the standard error of the curve and drawing a line defining the safe limit for, say, 95 per cent of the population' but they abandoned this approach for the following reason: 'unfortunately because of the non-linear form of the statistical model, it was not possible to establish a precise standard error of the expected tolerance time for any given climate.' It is true that non-linearity complicates the computation of the standard error of the expected tolerance time but their implication that they were unable to compute the exact tolerance intervals for this reason must be rejected. The non-linearity makes it difficult to compute either the tolerance intervals or the standard error, or both. The alternative they give is that the 'standard deviation of the 5 Oxford subjects' means may be taken and multiplied by a constant factor to provide an estimate of the position of the safe tolerance limit for 95 per cent of the population'. The constant factor they suggest is the "one-tailed " $t$ " value giving 95 per cent confidence limits'. The value they give for this is $1 \cdot 67$. We fail to see where they get this value from in the ' $t$ ' tables and we are of the view that this constant factor should be considerably more than $1 \cdot 67$. It should be borne in mind that our present conclusions were reached from studies on well-acclimatized men. The curves might well be shifted to the left for less well-acclimatized men. Another reservation must also be expressed about the conclusions given above. The samples of Io men, at each of the five wet-bulb temperature conditions, are rather small. Nevertheless the rectangular hyperbola fitted the data very well and there were no technical difficulties in dealing with the distributions of tolerance times of the different samples at the various wet-bulb temperature conditions.

A limitation to the conclusions arises from the fact that the men were cool when they first entered the climatic chamber. This resulted in a slower rate of rise in rectal temperature in the first hour than in the second hour of exposure in all the air conditions studied. The probable explanation for the difference lies in the heat capacity of the tissues in the periphery of the body. These tissues represent about one-third of the mass of the body. Their heat 
capacity is therefore about $10 \mathrm{Cal} . /^{\circ} \mathrm{F}$. In raising the temperature of the periphery from $86^{\circ} \mathrm{F}$. to $93^{\circ} \mathrm{F}$., which is roughly the change in skin temperature that can be expected in the first hour of exposure, about $70 \mathrm{Cal}$. heat would be absorbed by the peripheral tissues. This is similar to the rate of metabolic heat production per hour of men at rest. Once the peripheral tissues have been heated, the temperature of the body, as a whole, rises rapidly.

Men who have worked for some hours in hot conditions would not have cool skins and peripheral tissues, and therefore would not have the protection of the heat capacity of the cool peripheral tissues. Without this protection body temperatures would rise immediately the men entered very hot air. It can be assumed that, after some hours of work in ordinary hot conditions, the men would have rectal temperatures of at least $100 \cdot 0^{\circ} \mathrm{F}$. In wet-bulb temperatures of $104{ }^{\circ} \mathrm{F}$. and $102{ }^{\circ} \mathrm{F}$., rectal temperatures continued to rise in a straight line until they reached $104^{\circ} \mathrm{F}$., i.e., there was no tendency to reach a steady level. Therefore, we can calculate for these conditions the rates of rise in rectal temperature of such men to $104^{\circ} \mathrm{F}$., on the basis of the rates of rise in rectal temperature in the second hour of exposure. Calculated in this way, the average time for the rectal temperatures of the men to reach $104^{\circ} \mathrm{F}$. would be about I hour at $104^{\circ} \mathrm{F}$. W.B. and the average time for the men at $102^{\circ} \mathrm{F}$. W.B. would be about $1 \frac{1}{2}$ hours. At $100^{\circ} \mathrm{F}$. W.B. and below there was a tendency for the rectal temperatures of most men to reach a steady state. Therefore, the calculation of the rate of rise in rectal temperature based on the second hour measurements does not apply. However, as a reasonable approximation of the average times taken to reach rectal temperatures of $104^{\circ} \mathrm{F}$. under these air conditions I hour can be subtracted from the tolerance times given earlier in Table V. Based upon this assumption, the times are given in Table VI as a guide to the periods of exposure before which men would reach the limit of their tolerance if their body temperatures were $100^{\circ} \mathrm{F}$. at the time they encountered the very hot and humid conditions.

Comparison with the Results of Other Research Workers Attempts to compare these results with those of other research workers strikingly illustrate the differences in the criteria used for judging when the subjects had reached the limit of their tolerance.

The criterion used by MacPherson (1960) on nine acclimatized naval ratings, sitting in shorts, at a saturated air temperature of $99^{\circ} \mathrm{F}$. was: 'nearly all remained in the climatic chamber until they were on the point of collapse and most had to be assisted from the room.' The average rectal temperature of the men when they left the climatic chamber was IOI $66^{\circ} \mathrm{F}$. The criteria used by Provins and his colleagues (1962) on eight partially acclimatized men, sitting in boiler suits, was: ' . . . he (a physiologist) decided upon the experimental end point from an appraisal of the pulse rate and oral temperature record and the subject's appearance and comments'. The levels of pulse rate and oral temperature, judged to be the physiological limits, were not specified in the 1962 paper. The shortcomings of the criteria of Provins and his colleagues are brought out in a later paper (Bell and others, 1965) from this group in which they comment: 'Earlier experiments had shown that predetermined levels of body temperature and heart rate were not good indices of when heat exposure should end under these severe conditions.' ' . . experienced observers, who were constantly with the subjects, decided when collapse was about to occur and the exposure should be terminated'. Goldman and his colleagues (I965) employed the following criteria on samples of Io acclimatized and unacclimatized men: (I) when the rectal temperature reached $102.5^{\circ} \mathrm{F}$., or (2) when the heart rate reached 180 beats $/ \mathrm{min}$., or (3) when the medical officer considered that the reactions were excessive, such as tetany due to uncontrollable hyperventilation.

It is obvious that these research workers have different concepts from each other and from our

TABLE VI

\begin{tabular}{|c|c|c|c|c|}
\hline \multirow{2}{*}{ W.B. Temp. } & \multicolumn{2}{|c|}{$\begin{array}{c}\text { Time before which 'Average' Man would } \\
\text { not reach Tolerance Limit }\end{array}$} & \multicolumn{2}{|c|}{$\begin{array}{c}\text { Time before which at least } 99 \text { in Ioo Men } \\
\text { would not reach Tolerance Limit }\end{array}$} \\
\hline & Cool at Outset & Hot at Outset & Cool at Outset & Hot at Outset \\
\hline $\begin{array}{l}104^{\circ} \mathrm{F} . \\
102^{\circ} \mathrm{F} . \\
100^{\circ} \mathrm{F} . \\
98^{\circ} \mathrm{F} . \\
96^{\circ} \mathrm{F} .\end{array}$ & $\begin{aligned} 1 \frac{3}{4} \text { hours } \\
2 \frac{1}{2} \text { hours } \\
4 \frac{1}{4} \text { hours } \\
13 \frac{1}{2} \text { hours } \\
48+\text { hours }\end{aligned}$ & $\begin{array}{cl}\text { I } & \text { hour } \\
\text { I } \frac{1}{2} & \text { hours } \\
3 \frac{1}{4} \text { hours } \\
\text { I } 2 \frac{1}{2} \text { hours } \\
48+\text { hours }\end{array}$ & $\begin{array}{l}\text { I hours } \\
2 \text { hours } \\
2 \frac{3}{4} \text { hours } \\
5 \text { hours } \\
24 \frac{1}{2} \text { hours }\end{array}$ & $\begin{array}{l}\frac{1}{2} \text { hour } \\
\text { I hour } \\
\text { I hours } \\
4 \text { hours } \\
23 \frac{1}{2} \text { hours }\end{array}$ \\
\hline
\end{tabular}


own of the end point of heat tolerance. The British research workers place the emphasis on heat collapse, but Provins and others rely on the subjective judgment of the observer to decide 'when collapse was about to occur'. In our view, this is a very difficult decision to make. In our studies of the heat reactions of different ethnic groups (Wyndham, Strydom, Morrison, Williams, Bredell, von Rahden, Holdsworth, van Graan, van Rensburg, and Munro, 1964), within the first half-hour of exposure men reached a point where collapse appeared imminent, but they were encourged to continue and completed the full four-hour period of the experiment without any further circulatory embarrassment at rectal temperatures between $103^{\circ} \mathrm{F}$. and $104^{\circ} \mathrm{F}$. Goldman and others (1965) state quite bluntly that their tolerance times are 'arbitrarily defined'. Certainly in our experience acclimatized men can continue to work in heat without difficulty for four or more hours with a rectal temperature above $102.5^{\circ} \mathrm{F}$. but not above $104^{\circ} \mathrm{F}$. (Wyndham and others, 1964). It has also been our experience that acclimatized men can continue to work for some hours in hot conditions with heart rates of 180 beats $/ \mathrm{min}$., whereas in comfortable air temperatures a rate of work which produces a heart rate of $\mathrm{I} 80$ beats $/ \mathrm{min}$. is generally

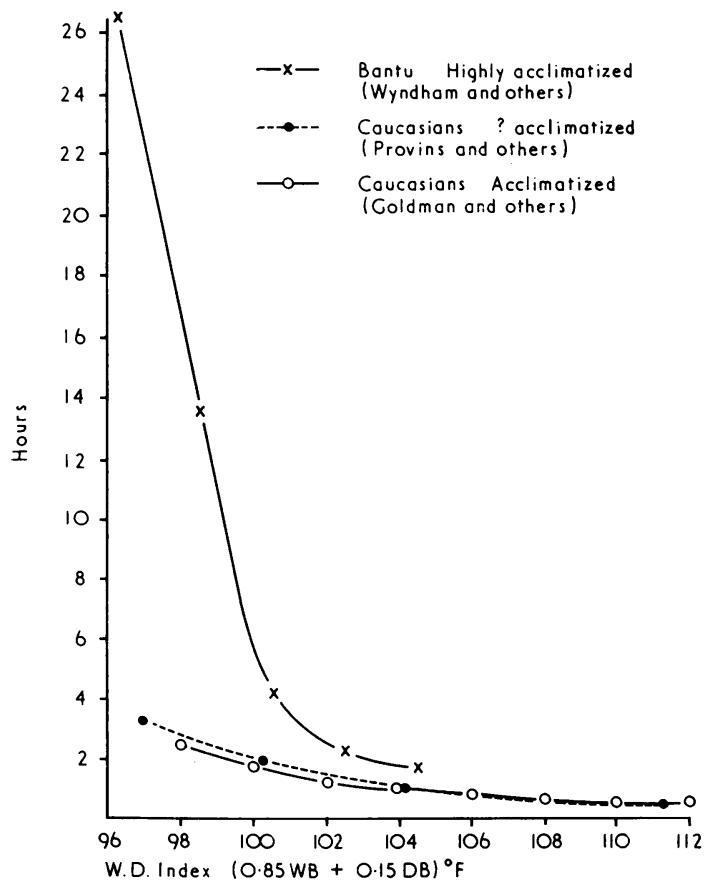

FIG. 6. Tolerance times at various W.D. heat stress index values. close to the maximum the individual can attain on aerobic metabolism and it can be kept up for only Io to 15 minutes. For these reasons the criteria of Goldman and his colleagues (1965) do not appear to us to be sound for deciding when men have reached the limit of their tolerance to heat.

In view of the criticisms given above of the criteria used by various research teams for deciding when men have reached the limit of their tolerance to heat, it is important to compare the results from those research workers with our own in which objective and more severe criteria were employed. This is done in Fig. 6 in terms of Lind's (1964) 'W.D.' index which takes the form: 0.85 W.B. + 0.15 D.B. Other combinations of W.B. and D.B. have been shown by Walters (1965) to give equally sound results but Provins and his colleagues (I962) and Goldman and his co-workers (I965) have expressed their results in terms of the W.D. index and hence comparison with present results is made more simple on this basis.

Figure 6 shows that the curves given by Provins and others and Goldman and his colleagues are closely similar. It also brings out the fact that the tolerance times predicted from their curves are very much shorter than those predicted from the curve based upon the present results. For example, at $98^{\circ} \mathrm{F}$. W.D. index, Provins et al. and Goldman et al. would both predict that the 'average' man would reach the limit of tolerance at $2 \frac{1}{2}$ hours. The 'average' acclimatized Bantu would only reach the limit after 14 hours, and even 99 in 100 acclimatized Bantu would not have reached the limit of heat tolerance before 5 hours at this W.D. index level. Similar differences are shown at other W.D. index levels.

The very large differences in tolerance times between the present results and those of other research workers require an explanation. One possible reason lies in the differences in criteria used for withdrawing men from heat. In our view, the criteria used by the two research teams referred to have little relationship to the men's chances of survival. They refer rather to the men's abilities to endure the severe discomfort of very high air temperatures. The ability to go on with a task under severe stress, be it heat, cold, altitude or endurance exercise, is a function of the men's motivations. These are a complex interplay of their basic drives to do well and the leadership given to them. Wellmotivated men under good leadership will go on with a stressful task until they drop; others, where these qualities are lacking, will give up easily.

Another possible reason for the differences in results might lie in the greater circulatory stability of the Bantu compared with the European. Weiner 
(1938) first drew attention to this difference. A comparison between the results on MacPherson's (1960) nine acclimatized European naval ratings and ours on 50 acclimatized Bantu supports Weiner's conclusion. Most of the naval ratings were on the point of collapse and had to be assisted from the room. Their mean rectal temperature was ror $\cdot 6^{\circ} \mathrm{F}$. and the mean heart rate 140 beats/minute. Not one of the 50 Bantu subjects suffered from heat collapse, although 36 had rectal temperatures of $104^{\circ} \mathrm{F}$. and many had heart rates of 140 beats $/ \mathrm{min}$. for some hours. A further point in favour of the greater circulatory stability of the Bantu is that the mean rectal temperature of $103^{\circ} \mathrm{F}$. was associated with a mean heart rate of only I Io beats $/ \mathrm{min}$. (at $96^{\circ} \mathrm{F}$. W.B.) compared with the heart rate of 140 beats/ min. at a mean rectal temperature of $101 \cdot 6^{\circ} \mathrm{F}$. in MacPherson's naval ratings.

Another explanation for the discrepancies in results might lie in the differences in the states of acclimatization of the various groups of subjects and, in the study by Provins and others (1962), because subjects wore boiler suits. The subjects of Provins et al. were not formally acclimatized to heat but, as they were 'exposed twice on each day', it can be presumed that as the experiment progressed they would have acquired a certain degree of acclimatization to heat. At $100^{\circ} \mathrm{F}$. on the W.D. index the mean tolerance time of the subjects used by Provins and others was approximately 60 minutes. MacPherson's subjects were acclimatized and their mean tolerance time at $99^{\circ} \mathrm{F}$. W.D. index was I44 minutes. Goldman and his colleagues (I965) did not find any significant difference between acclimatized and unacclimatized men in the tolerance time of 110 minutes at $100^{\circ} \mathrm{F}$. W.D. index. The tolerance time for the highly acclimatized Bantu at $100^{\circ} \mathrm{F}$. W.D. index was 325 minutes. Recent and as yet unpublished results on unacclimatized Bantu indicate that their tolerance time at this W.D. index level will be about 120 minutes. Acclimatization, in our view, has a very marked effect, therefore, on the length of time men are able to tolerate very high heat and humidity. This would make untenable the proposal by Goldman and others (1965) that the body acts as a physical object in its heating properties above $96^{\circ} \mathrm{F}$. W.D. index value.

Psychological Disturbances and E.E.G. Changes The marked psychological disturbances that occur when men are exposed to severe heat have been well described by MacPherson (1960) in the studies made towards the end of the r950s on European naval ratings in the Medical Research Council Tropical Research Unit at Singapore. Nine acclimatized men were exposed at rest in an air condition of $99^{\circ} \mathrm{F}$. (with the air saturated with water vapour) and a wind velocity of $150 \mathrm{ft} /$ minute. A frequent symptom was '. . . a compelling desire to get out of the heat at any cost'. A less frequent symptom was 'outbursts of weeping'. Other emotional disturbances were seen: 'They became either euphoric and talkative, or morose, irritable and suspicious and these attitudes sometimes alternated during the same experiment.' MacPherson considered that the clinical picture had features which are reminiscent of anoxia.

In the present studies on Bantu subjects, the main emotional change was aggressiveness. Other changes in temperament were hysteria with crying and weeping, apathy, and a refusal to follow instructions. About $50 \%$ of the subjects showed emotional changes of one sort or another. Because of this it would be difficult to handle such men in an orderly and disciplined way in the event of an emergency. These psychological reactions to heat of men exposed to very high wet-bulb temperatures raise the question of whether it would be possible to keep control of a body of men in the event of their being exposed to severe heat for some hours. Their changes in temperament might lead to their failing to follow instructions. However, in this regard some importance can be attributed to the observations that in the 48-hour experiment at $96^{\circ} \mathrm{F}$. some of the subjects became impossible to handle, but even in these circumstances they responded to a senior hostel official, whom they respected; he talked to them in their own language and they became calm. This suggests that the men were still susceptible to good leadership even in these very adverse and stressful conditions. The changes in temperament did not return to normal with the fall in rectal temperature after the experiment. Some men remained aggressive for some hours after leaving the heat.

In the long 48 -hour study at $96^{\circ} \mathrm{F}$. a feature of the behaviour of the men was the cyclical nature of the aggressiveness and apathy. The latter state was associated usually with the men sleeping or trying to sleep. They were at their most aggressive during the day.

The E.E.G. studies brought out the fact that five of the six men who became very aggressive had low alpha frequencies. In addition, the man who became violent and assaulted an observer had an abnormal E.E.G. which was suggestive of an epileptic disorder. However, such temporal lobe foci also occur in non-epileptic psychopaths and in persons convicted of crimes of violence. In none of the other 44 subjects were E.E.G. abnormalities of any kind evoked or caused by exposure to heat. 
From these findings it can be concluded that raising the body temperature to $104^{\circ} \mathrm{F}$. for a few hours does not result in any abnormal electrical activity in the brain of normal individuals.

Body Temperature Responses There are certain academic issues of great interest in these results. The first is that the circadian rhythm in body temperature, which occurs in men in comfortable air conditions when their body temperatures are about $99.0^{\circ} \mathrm{F}$., is also seen in these conditions even though their rectal temperatures are between $102{ }^{\circ} \mathrm{F}$. and $103^{\circ} \mathrm{F}$. The temperatures are lowest in the late night and early morning hours, and are highest after midday. The circadian fluctuation is about $\mathrm{I} \cdot \mathrm{O}^{\circ} \mathrm{F}$. Oxygen consumptions were not measured, but it was observed that the men were deeply asleep at the time of the lowest rectal temperatures and were difficult to rouse. Rectal temperatures were highest during the day when the men were awake and some men were vociferous and aggressive. There may be an association between the circadian changes in rectal temperature and the variations in metabolism.

It is also of great interest that these circadian changes in body temperature are superimposed upon a body temperature regulated at $102^{\circ} \mathrm{F}$. to $103^{\circ} \mathrm{F}$. in high environmental temperatures. One might have expected that the regulation of body temperature to the high temperatures would damp out any minor adjustments, such as the circadian rhythm, but apparently this is not the case. It was also observed that once the body temperature had reached a steady level at between $102{ }^{\circ} \mathrm{F}$. and $103^{\circ} \mathrm{F}$., it was very sensitive to small changes in the environmental temperature, so that if the climatic room temperature fell by $0.5^{\circ} \mathrm{F}$. the rectal temperatures followed this change and fluctuated in phase with changes in climatic room temperatures. This also was unexpected. These two observations suggest that once the temperatureregulating mechanism makes its main adjustment to a severe external heat load the body then acts like a semi-poikilotherm to minor changes in the external temperature and in metabolism.

Another point of academic interest is the rate of rise in rectal temperature. If the body at rest loses no heat to the environment and all the resting metabolic heat, approximately 60-70 $\mathrm{Cal}$./hour, is employed in raising the body temperature then in a man with a heat capacity of $30 \mathrm{Cal}$./hour per ${ }^{\circ} \mathrm{F}$. the body temperature will rise at the rate of approximately $2{ }^{\circ} \mathrm{F}$. per hour. At $\mathrm{r} 04^{\circ} \mathrm{F}$. the average maximum rate of rise (in the second hour) was just over $4^{\circ} \mathrm{F}$. per hour and therefore there must be a gain in heat of $30 \mathrm{Cal}$./hour from the environment. At $102^{\circ} \mathrm{F}$. the average maximum rate is $2 \cdot 70^{\circ} \mathrm{F}$. per hour and at $100^{\circ} \mathrm{F}$. W.B. it is $2.44^{\circ} \mathrm{F}$., indicating that in both instances there is a small positive gain of heat from the environment. At $98^{\circ} \mathrm{F}$. the average maximum rate of rise is $1 \cdot 7^{\circ} \mathrm{F}$., indicating that the rate of heat loss just exceeds the rate of heat production. From the rates of rise in body temperature in the second hour of exposure one could predict, therefore, whether men at rest in a particular environment would reach a steady level of body temperature or not.

Circulatory Reactions Heart rates rose to maximum levels of $140-150$ beats $/ \mathrm{min}$. within 30 minutes in these conditions of severe heat. This indicates that the heart and circulation respond rapidly to meet the increase in the circulation of blood in the skin and subcutaneous regions. The initial rapid increase in heart rate is associated with a rise in both skin and core temperatures. However, heart rate generally reaches a steady level $30 \mathrm{~min}$. after the man has entered the hot room, but the rectal temperature continues to rise. At that time, therefore, the reactions of heart rate and rectal temperature to heat are dissociated.

The maximum heart rates reached by the men, either sitting at rest or lying down in severe heat, were between 140 and 150 beats/minute. These maximum heart rates are lower than those recorded when men work in heat (Wyndham et al., I964). In such circumstances heart rates of 180 to 190 beats $/ \mathrm{min}$. are recorded. It appears, therefore, that both muscular work and an increase in body temperature are needed to attain heart rates close to 200 beats / $\mathrm{min}$.; increased work rate is apparently the more powerful stimulus to heart rate.

The rate of rise in heart rate in the first hour of exposure appears to be a good index of the length of time the men will be able to tolerate the conditions of heat. In an internal report of this laboratory in I957 we showed that if heart rates rose to 125 beats / min. or more in the first hour of heat exposure, the men would not be able to tolerate the conditions for more than two or three hours. The present results support this finding. At $104^{\circ} \mathrm{F}$, , $102^{\circ} \mathrm{F}$., and $100^{\circ}$ F. W.B., mean heart rates were above I25 beats $/ \mathrm{min}$. at the end of one hour and the men could not tolerate the conditions for more than three or four hours. At $98^{\circ} \mathrm{F}$. and $96^{\circ} \mathrm{F}$. W.B. the mean heart rates were $\mathrm{r}$ ro and 94 beats/min. respectively, and the men remained in these temperatures for a mean period of $15 \frac{1}{2}$ hours and 48 hours respectively.

A number of physiologists (Weiner, 1938; 
Wyndham et al., 1964) have drawn attention to the greater stability on exposure to heat of the circulatory system of the Bantu compared with that of the Caucasian. The present results support this conclusion. The greater stability of the circulatory system apparently is not associated with any difference in physical fitness. Measurements of the maximum oxygen intakes of Bantu and Caucasian men of similar age and state of training in this laboratory (Wyndham, Strydom, Morrison, Peter, Williams, Bredell, and Joffe, 1963) have shown that the two ethnic groups are almost identical when their maximum oxygen intakes are expressed per kilogram of body weight. The greater circulatory stability of the Bantu is undoubtedly one of the most important reasons for their ability to tolerate very severe heat and humidity for much longer periods than the Caucasians.

Water Exchanges These studies brought out a number of important points regarding water exchanges in extreme heat and humidity. The losses of water in sweat are relatively small at temperatures up to $98^{\circ} \mathrm{F}$. W.B., being less than $200 \mathrm{ml}$./hour. Above $98^{\circ} \mathrm{F}$. W.B. the rate of sweating increases markedly, rising to $300 \mathrm{ml}$./hour at $100^{\circ} \mathrm{F}$. and to $800 \mathrm{ml}$./hour at $102^{\circ} \mathrm{F}$. Normally the body has a water turnover of about $\mathrm{I}, 500 \mathrm{ml}$./ day, comprising certain 'obligatory' water losses in urine, in order to rid the body of waste products, and also losses in the faeces and respiratory tract and from the skin. Even at the lowest rates of sweating, at $96^{\circ} \mathrm{F}$., the body will lose about $3,600 \mathrm{ml}$./day of water in sweat. It will be clear, therefore, that these high water losses in sweating will place a stress on the body in adjusting to a new water balance.

The first point that emerged in this regard was that the water intake of the subjects did not adjust closely to the water losses in circumstances of extreme heat. Above $98^{\circ} \mathrm{F}$. W.B. the water intake lagged further and further behind the rate of water loss in sweat and in the urine as the air temperature rose, and consequently the degree of dehydration increased progressively with the rise in wet-bulb temperature. Similar results have been reported by Wyndham, Bouwer, Devine, and Paterson (1952) and by other investigators (Kenney, 1954; Pitts, Johnson, and Consolazio, 1944). However, the final state of dehydration of the subject is a product of both the rate of dehydration and the duration of the exposure. Thus even though the rates of dehydration were high at $104^{\circ} \mathrm{F}$. and $102^{\circ} \mathrm{F}$. W.B. the length of exposure was short and the final state of water deficit was less than $\mathrm{I}, 500 \mathrm{ml}$. At $96^{\circ} \mathrm{F}$. W.B. the rate of dehydration was relatively slow but its cumulative effect over the 48 hours was such that 4 the average total water deficit was 3,500 $\mathrm{ml}$., approximately $6 \%$ of man's body weight.

Another point of importance was that at $96^{\circ} \mathrm{F}$. W.B., even when the rate of water intake exceeded the losses in sweat, the subjects did not achieve a state of water balance. At $96^{\circ} \mathrm{F}$. W.B. the men drank an average of $7,600 \mathrm{ml}$. of water over the 48 hours and sweated less than $6,500 \mathrm{ml}$., but they ended up dehydrated to the extent of $3,500 \mathrm{ml}$. because they passed $4,600 \mathrm{ml}$. in urine. The urine loss of approximately $90 \mathrm{ml}$./hour is nearly twice the minimum 'obligatory' loss of fluid in urine and indicates that the large water intake of $7,600 \mathrm{ml}$. in the 48 hours, approximately $150 \mathrm{ml}$./hour, had caused a diuresis, in spite of the high total sweat loss. It is possible that the diuresis occurred because the men drank large quantities of water once every hour instead of taking small amounts at more frequent intervals. The latter regime might have prevented the diuresis to some extent. Previous reports have been made on the diuretic effect of large quantities of water intake notwithstanding a state of dehydration of considerable magnitude (Kenney, 1954).

Another point that emerged from this study was that in all the short exposures, i.e., at wet-bulb temperatures above $98^{\circ} \mathrm{F}$., the total water deficit was relatively constant, being between 1,000 and $\mathrm{I}, 500 \mathrm{ml}$. This was the case in spite of the very large difference in rates of water intake. One could conclude that in short-term disturbances of water balance the body allows itself to dehydrate voluntarily to about $\mathrm{I}, 000-\mathrm{I}, 500 \mathrm{ml}$. before the stimulus is provided for the drinking of large quantities of water. However, this did not appear to apply during very long exposures to heat. In these circumstances the men drank relatively large quantities of water at infrequent intervals and this resulted in a diuresis. The combined effect of sweating and diuresis led insidiously to a large total average water deficit of about $3,500 \mathrm{ml}$. Even in these circumstances, however, the extent of voluntary dehydration, apart from the diuresis, is still about $\mathrm{r}, 500 \mathrm{ml}$. This can be estimated from the fact that the obligatory water losses in urine would be about $2,400 \mathrm{ml}$. in the 48 hours. The average urine output was $4,600 \mathrm{ml}$. The difference between these two urine volumes, $2,200 \mathrm{ml}$., is the actual volume of the diuresis. If this quantity is subtracted from the total water deficit of $3,500 \mathrm{ml}$. it leaves $1,300 \mathrm{ml}$., which is similar to the water deficit seen in the other conditions. This would seem to suggest that most of the water deficit was in the intracellular space. It would be interesting to see whether a better water regime, in which small quantities are taken frequently, would pre- 
vent diuresis or whether drinking isotonic saline instead of plain water would help to prevent the water loss in urine.

Water Requirements The minimum water requirements of men at rest in these various conditions of extreme hot, humid heat can be calculated from sweat rates and an arbitrary figure for the obligatory water losses in urine which can be taken as $60 \mathrm{ml}$./hour. On this basis the water requirements per man at the various wet-bulb temperature conditions were calculated and are given in Table VII.

\section{TABLE VII}

WATER ReQUirements OF MEN AT DIFFERENT W.B. TEMPERATURES

\begin{tabular}{c|c}
\hline W.B. Temperature & Water Requirements \\
\hline $96^{\circ} \mathrm{F}$. & $180 \mathrm{ml} . / \mathrm{hr}$ \\
$98^{\circ} \mathrm{F}$. & $225 \mathrm{ml} . / \mathrm{hr}$ \\
$100^{\circ} \mathrm{F}$. & $350 \mathrm{ml} . / \mathrm{hr}$ \\
$102^{\circ} \mathrm{F}$. & $860 \mathrm{ml} . / \mathrm{hr}$ \\
$104^{\circ} \mathrm{F}$. & $930 \mathrm{ml} . / \mathrm{hr}$ \\
\hline
\end{tabular}

It would be only at $96^{\circ} \mathrm{F}$. W.B. and below that men would tolerate heat long enough to make the provision of water a problem. Here the requirement would be approximately 5 litres/man/day or I gallon/man/day. This should be taken preferably in small quantities, i.e., a large mouthful (6o ml.) every 15 to 20 minutes. In this way the diuresis which results from drinking large quantities of water every hour might be avoided.

This paper is published with the permission of the Transvaal and Orange Free State Chamber of Mines, Johannesburg, South Africa.

\section{REFERENCES}

Bell, C. R., Hellon, R. F., Hiorns, R. W., Nicol, P. B., and Provins, K. A. (1965). Safe exposure of men to severe heat. F. appl. Physiol., 20, 288-292.

Goldman, R. F., Green, E. B., and Iampietro, P. F. (1965). Tolerance of hot, wet environments by resting men. Ibid., 20, 27 I-277.

Iampietro, P. F., and Goldman, R. F. (1965). Tolerance of men working in hot, humid environments. Ibid., 20, 73-76.

Kenney, R. A. (1954). The effect of the drinking pattern on water economy in hot, humid environments. Brit. $\mathcal{F}$. industr. Med., 11, 38-39.

Lind, A. R. (1964). In Heat Stress and Heat Disorders. Ed. Leithead, C. S., and Lind, A. R. Cassell, London.

MacPherson, R. K. (1960). In Physiological Responses to Hot Environments. Spec. Rep. Ser. med. Res. Coun. (Lond.), No. 298.
Nelson, G. K. (1965). The electroencephalogram and behaviour under conditions of high temperature and humidity. C.S.I.R. Special Report.

Pitts, G. C., Johnson, R. E., and Consolazio, F. C. (1944). Work in heat as affected by intake of water, salt and glucose. Amer. F. Physiol., 142, 253-259.

Provins, K. A., Hellon, R. F., Bell, C. R., and Hiorns, R. W. (1962). Tolerance to heat of subjects engaged in sedentary work. Ergonomics, 5, 93-97.

Walters, J. D. (1965). Human endurance in intolerable climates. Roy. Nav. med. F., 51, 208-221.

Weiner, J. S. (1938). An experimental study of heat collapse. f. industr. Hyg., 20, 389-400.

Wyndham, C. H., Strydom, N. B., Morrison, J. F., Peter, J., Williams, C. G., Bredell, G. A. G., and Joffe, A. (1963). Differences between ethnic groups in physical working capacity. F. appl. Physiol, 18, 361-366.

,,-- Williams, C. G., Bredell, G. A. G. von Rahden, M. J. E., Holdsworth, L. D., van Graan, C. H., van Rensburg, A. J., and Munro, A. (1964). Heat reactions of Caucasians and Bantu in South Africa. Ibid., 19, 598-606.

v.d.m. Bouwer, W., Devine, M. G., and Paterson, H. E. (1952). Effect of exercise and environment on urine secretion after a water load. Ibid., 5, 285-289.

\section{APPENDIX}

\section{Statistical Method of Analyses}

Any relation expressing the mean survival time (y) as a function of W.B. temperature (x) can, for a priori reasons, be expected to possess the following two characteristics:

(a) $\mathrm{y} \rightarrow 0$, as $\mathrm{x} \rightarrow \infty$; that is, there would be a horizontal asymptote along the $\mathbf{x}$-axis as $\mathbf{x} \rightarrow \infty$, and

(b) $\mathrm{y} \rightarrow \infty$, as $\mathrm{x} \rightarrow \mathrm{a}+$ for some critical wet-bulb temperature a, below which heat stroke (for example) is not expected to occur.

The behaviour of the first group of subjects suggests that: $96^{\circ} \mathrm{F} .<\mathrm{a}<98^{\circ} \mathrm{F}$.

The simplest function satisfying the above two requirements is the two-parameter rectangular hyperbola:

$$
\text { or } \begin{aligned}
y & =\frac{b}{x-a} \\
\frac{I}{y} & =\frac{I}{b} x-\frac{a}{b}
\end{aligned}
$$

In order, therefore, both to verify the preceding argument and to estimate $a$ and $b$, the inverse times of survival $\frac{I}{y_{i j}}$ were plotted against the four higher W.B. temperatures $x_{i}$. It was found that this transformation not only yielded the expected straight line but appeared to transform the distribution of survival times at each of the four W.B. temperatures 
APPENDIX TABLE

\begin{tabular}{|c|c|c|c|c|c|c|c|c|}
\hline \multirow{2}{*}{$\begin{array}{c}\text { Wet Bulb Temp. } \\
(\mathrm{x})\end{array}$} & \multicolumn{2}{|c|}{ P 50\% } & \multicolumn{2}{|c|}{ P 75\% } & \multicolumn{2}{|c|}{ P $90 \%$} & \multicolumn{2}{|c|}{ P 99\% } \\
\hline & $y_{2}$ & $y_{1}$ & $y_{2}$ & $y_{1}$ & $\mathrm{y}_{2}$ & $y_{1}$ & $\mathrm{y}_{2}$ & $y_{1}$ \\
\hline 96 & - & - & - & - & - & - & - & 24.50 \\
\hline 97 & - & - & - & $20 \cdot 25$ & - & 13.50 & - & 9.50 \\
\hline 98 & $26 \cdot 50$ & $9 \cdot 25$ & 35.00 & $7 \cdot 75$ & - & 6.50 & - & 5.00 \\
\hline 99 & $8 \cdot 50$ & 5.50 & 10.50 & $4 \cdot 75$ & 13.75 & $4 \cdot 25$ & 39.00 & 3.50 \\
\hline 100 & $5 \cdot 00$ & 3.75 & $5 \cdot 50$ & $3 \cdot 50$ & 6.25 & 3.00 & 9.00 & $2 \cdot 75$ \\
\hline IOI & 3.50 & 3.00 & 4.00 & $2 \cdot 50$ & 4.25 & $2 \cdot 50$ & 5.25 & $2 \cdot 25$ \\
\hline 102 & $2 \cdot 75$ & 2.25 & 3.00 & $2 \cdot 00$ & $3 \cdot 25$ & $2 \cdot 00$ & 3.75 & $2 \cdot 00$ \\
\hline 103 & 2.25 & $1 \cdot 75$ & $2 \cdot 50$ & $I \cdot 75$ & $2 \cdot 50$ & I. 75 & 3.00 & $I \cdot 75$ \\
\hline 104 & $2 \cdot 00$ & $1 \cdot 50$ & $2 \cdot \infty$ & 1.50 & $2 \cdot 25$ & $I \cdot 50$ & $2 \cdot 50$ & $1 \cdot 25$ \\
\hline
\end{tabular}

into four normal distributions with common variance. Thus it was possible to fit, immediately, normal two-sided tolerance limits to the transformed data enclosing different proportions $\mathbf{P}$ of the parent population. These reconverted back to the original variables are given in the Appendix Table. They enable one, at a confidence level of $95 \%$, to predict between what times $y_{1}=y_{1}(x, P)$ and $y_{2}=y_{2}$ $(x, P)$ at least $P$ men out of every 100 will reach withdrawal levels at a W.B. temperature of $\mathbf{x}$. Thus one may state with $95 \%$ confidence that at least $\mathrm{P} \%$ of the population will not yet be in danger of heat stroke at time $y_{1}$, although at least $\mathrm{P} \%$ of the population will have succumbed by time $y_{2}$. Two-sided limits permit the making of both statements at the specified level of confidence, whereas the level of confidence for two one-sided limits would have to be reduced if they were quoted simultaneously.

The Appendix Table derived from Fig. 5 gives the values of $y_{1}$ and $y_{2}$ with $P$ equal to $99 \%, 90 \%, 75 \%$, and $50 \%$, and various values of $x$.

In conclusion it should be pointed out that a hyperbola fitted by the above procedure will give a biased estimate of the expected survival time $E(y)$ for a given $\mathrm{x}$ since the value given by the hyperbola is actually the expected harmonic mean $\frac{I}{E\left(\frac{I}{y}\right)}$ which is generally less than $\mathrm{E}(\mathrm{y})$. 